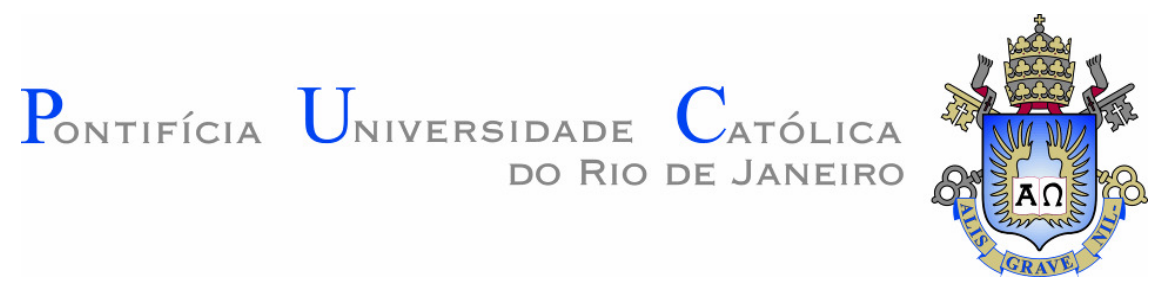

Guilherme Lima Cardozo

A questão da linguagem nas epístolas de Paulo aos romanos e aos coríntios

\author{
Dissertação de Mestrado
}

Dissertação apresentada ao Programa de PósGraduação em Estudos da Linguagem da PUC-Rio como requisito parcial para obtenção do grau de Mestre em Estudos da Linguagem

Orientador: Prof ${ }^{\mathrm{a}}$. Helena Franco Martins

Rio de Janeiro Março de 2013 


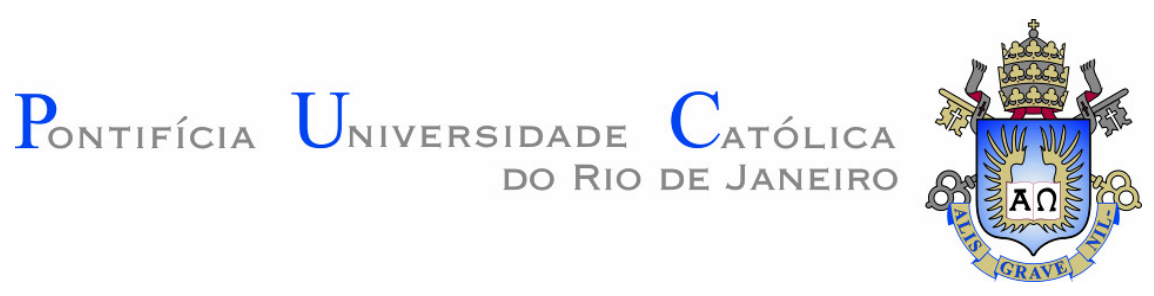

Guilherme Lima Cardozo

\section{A QUESTÃO DA LINGUAGEM NAS EPÍSTOLAS DE PAULO AOS ROMANOS E AOS CORÍNTIOS}

Dissertação apresentada como requisito parcial para obtenção do grau de Mestre pelo Programa de Pós-Graduação em Estudos da Linguagem do Departamento de Letras do Centro de Teologia e Ciências Humanas da PUC-Rio. Aprovada pela Comissão Examinadora abaixo assinada.

Profa. Helena Franco Martins Orientadora Departamento de Letras - PUC-Rio

Profa. Maria Paula Frota

Departamento de Letras - PUC-Rio

Profa. Ana Paula Grillo El-Jaick UFJF

Profa. Denise Berruezo Portinari Coordenadora Setorial do Centro de Teologia e Ciências Humanas - PUC-Rio

Rio de Janeiro, 08 de março de 2013. 
Todos os direitos reservados. É proibida a reprodução total ou parcial do trabalho sem autorização da universidade, do autor e da orientadora.

\section{Guilherme Lima Cardozo}

Graduou-se em Letras, Bacharel em Línguas Portuguesa e Italiana pela Universidade Estadual do Rio de Janeiro, em 2009. É funcionário público do Tribunal de Justiça do Estado do Rio de Janeiro.

Ficha Catalográfica

Cardozo, Guilherme Lima

A questão da linguagem nas epístolas de Paulo aos romanos e aos coríntios / Guilherme Lima Cardozo ; orientador: Helena Franco Martins. 2013.

$111 \mathrm{f} . ; 30 \mathrm{~cm}$

Dissertação (mestrado)-Pontifícia Universidade Católica do Rio de Janeiro, Departamento de Letras, 2013.

Inclui bibliografia

1. Letras - Teses. 2. Paulo de Tarso. 3. Indizível. 4. Discurso apofático. 5. Metáfora. I. Martins, Helena Franco. II. Pontifícia Universidade Católica do Rio de Janeiro. Departamento de Letras. III. Título.

CDD: 800 


\section{Agradecimentos}

À Chiquinha, pela educação e disponibilidade constantes.

Às professoras da PUC-Rio, Maria Paula Frota, Maria das Graças Pereira, Érica Rodrigues e Bárbara Hemais, pelos grandes ensinamentos.

Aos colegas de mestrado Cinara Cortez, Christiano Sanchez e Juliana Menezes, por sempre me auxiliarem.

À minha mãe, Solange, ao meu irmão, Michel, e ao meu pai, Agostinho, por acreditarem, apoiarem e financiarem esse novo caminho que tracei em minha vida.

A meu amigo e professor José de Paiva Netto, cujas lições e ensinamentos forjaram meu caráter.

Ao amigo Tiago Batalha, o disparador psíquico dessa idéia de vida acadêmica.

A todos os meus parentes que vibraram pelo meu sucesso.

A Deus e a Jesus, que me inspiraram diretamente na feição deste trabalho final. 


\section{Resumo}

Cardozo, Guilherme Lima; Martins, Helena Franco. A questão da linguagem nas epístolas de Paulo aos romanos e aos coríntios. Rio de Janeiro, 2013. 111 p. Dissertação de Mestrado - Departamento de Letras, Pontifícia Universidade Católica do Rio de Janeiro.

O presente trabalho tem como objetivo investigar de que forma Paulo faz emergir das Escrituras Sagradas um pensamento sobre a linguagem, com foco em suas cartas aos romanos e aos coríntios. Testa-se a hipótese de que comparece ali uma perspectiva de linguagem pragmática. Dar-se-á ênfase especial a dois aspectos interligados: o modo como Paulo aborda, através de metáforas, a presença das metáforas nas Escrituras; e o modo como a questão do indizível e o gênero apofático se manifestam nas suas epístolas. Nas análises do presente estudo mostra-se que (a) apesar de haver passagens em que a metáfora é colocada no discurso tal qual uma espécie de ornamento, como um meio de obter o entendimento e a atenção dos ouvintes, conforme prevê a clássica teoria aristotélica, com a tensão letra x espírito, o apóstolo vem romper com o primado da literalidade e do significado próprio da palavra, em diversos momentos nos quais a metáfora, muito mais que agente de um impacto estético ou retórico, aparece como um recurso que permite uma aproximação indireta com Deus - o que permite entrever nos escritos paulinos elementos de teorias posteriores da metáfora, onde é tomada como fenômeno fundante; (b) ao tratar do tema do divino, Paulo the atribui sua característica de inefabilidade, consoante alguns pensadores gregos que lhe antecederam, porém, em seu discurso, a indizibilidade pode sair do campo do incognoscível e ser sondada pelas criaturas, contanto que se libertem da "letra que mata", pois através do "espírito" o homem pode conhecer a Deus - que é Espírito - "face a face"; (c) tornar o indizível cognoscível, pela atividade do espírito, não significa, absolutamente, torná-lo dizível.

\section{Palavras-chave}

Paulo de Tarso; indizível; discurso apofático; metáfora. 


\section{Abstract}

Cardozo, Guilherme Lima; Martins, Helena Franco (Advisor). The question of language in Paul's Epistles to the Romans and Corinthians. Rio de Janeiro, 2013. 111 p. MSc. Dissertation Departamento de Letras, Pontifícia Universidade Católica do Rio de Janeiro.

The present work aims to investigate in what way Paul makes a perspective of language emerge from the Scriptures, focusing on his Epistles written to the Romans and Corinthians. It is tested the hypothesis that there is a pragmatic perspective of language in these Epistles. Special emphasis is given to two interconnected aspects: the way with which Paul approaches, using metaphors, the presence of metaphors in the Scriptures; and the way that the issue of the unspeakable and the apophatic genre manifest in his Epistles. The analyses of selected passages shows mainly that (a) although there are passages in which metaphor is put in the discourse as a kind of ornament, or lure, as a way of obtaining the understanding and attention of listeners, just as classic Aristotelic theories predict, the Apostle, with the tension between letter and spirit, breaks away from the ideas of the primacy of literalness and intrinsic word meaning, in many occasions where metaphor, considered not only as mere agent of aesthetic or rhetoric impact, appears as a resource that enables an indirect approach to God - which is something that brings Paulo's perspective closer to later theories of metaphor in which it is taken as a founding phenomenon; (b) in order to approach the theme of the divine, Paul attributes to it the characteristic of ineffability, in accordance with some Greek intellectuals who preceded him; however, in his discourse, the unsayable can part off with the unknowable and be probed by humans, as long as they free themselves from the "letter that kills", once only through the "spirit" men can know God - who is Spirit - "face to face"; (c) rendering the unspeakable acknowledgeable, through the activity of the spirit, does not mean, unquestionably, making it sayable.

\section{Keywords}

Paul of Tarsus; unspeakable; apophatic discourse; metaphor. 


\section{Sumário}

$\begin{array}{ll}\text { 1. Introdução } & 9\end{array}$

1.1 Tema 9

$\begin{array}{ll}1.2 \text { Relevância da Pesquisa } & 10\end{array}$

1.3 Método de Pesquisa 12

1.4 Perguntas de Pesquisa 12

1.5 Breve contextualização: origens do discurso apofático 13

1.5.1 Alcino e o Didaskalicos 14

1.5.2. Plotino e a Enéada 15

1.5.3. Sobre Paulo de Tarso 16

2. Balizas teóricas 19

2.1. Práxis x Representação 19

2.1.1 A Lógica do século XIX 28

2.1.2 Sobre a Potência $\quad 29$

2.2. Metáfora fundada x Metáfora fundante 32

2.3. Dizível x Indizível 45

2.4. Paulo e a linguagem 63

3. Análise das epístolas $\quad 67$

3.1. A Letra e a Lei 67

3.1.1 O Ser em potência $\quad 74$

3.2. A questão metáfora 76

3.2.1. A metáfora instrutiva 76

3.2.2. O sentido incapturável e a metáfora predicativa 81

3.3. O espírito e a letra 84

3.4. A Escritura contra a Escritura 85

3.5. O indizível nas cartas paulinas 96

3.5.1. O nome de Deus 88

3.5.2. O Nome que chama 90

3.5.3. O dom, a eucaristia e a alteridade 94

3.5.4. A saga do Espírito no universo do indizível 97 
4. Considerações finais

5. Referências

109

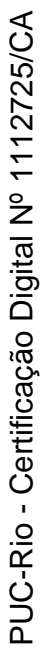

